\title{
CRITERIA FOR ESTIMATING THE SENSORIMOTOR REACTION TIME BY THE SMALL UAV OPERATOR
}

Vakaliuk T. A. - Dr. Sc., Professor, Professor at the Department of software engineering, Zhytomyr Polytechnic State University, Zhytomyr, Ukraine.

Pilkevych I. A. - Dr. Sc., Professor, Professor at the Department of computer information technologies, Zhytomyr military institute named after S. P. Korolov, Zhytomyr, Ukraine.

Tokar A. M. - PhD, Head of the Division of science center, Zhytomyr military institute named after S. P. Korolov, Zhytomyr, Ukraine.

Loboda R. I. - Research Officer of the Division of science center, Zhytomyr military institute named after S. P. Korolov, Zhytomyr, Ukraine.

\section{ABSTRACT}

Context. The rapid development of science and technology predetermines a significant expansion of the fields of application of UAVs different purposes. The key to the effective use UAVs is high-quality training of operators, an important element of which is the PPS of candidates, in particular, the assessment of their sensorimotor reactions. This can be achieved by selecting and justifying appropriate criteria.

Objective. The goal of the work is the justification criteria for estimating the time sensorimotor reactions of a small UAV operator by analyzing the density distribution of statistical data.

Method. A method has been developed to determine criteria for evaluating the time of sensorimotor reactions a small UAV operator based on the accumulation statistical material and its mathematical processing based on the results of a field experiment. The method allows to estimate numerical characteristics the distribution of the average reaction time in three modes: training production, in the conditions overload, in the conditions of overtraining and to obtain a generalized estimation. It was possible, by analyzing the occasional noninterruptible values, which take values within a certain range of values, to establish standards against which the obtained values the sensorimotor reaction time of the small UAV operator are compared and a decision is made on their suitability for training.

Results. We obtained statistical series for the modes of assessment: skill development, under obstacle conditions, under conditions skill restructuring. For a visual representation of the series the corresponding histograms the distribution of the average reaction time duration were constructed. In order to eliminate the representativeness error, statistical series alignment was carried out by selecting a theoretical distribution curve for each series, which displays only essential features of the statistical material. For this purpose, we approximated the histogram of distribution by the polynomialf fourth degree. The interval theoretical density of distribution, in which the time sensomotor reaction of an arbitrary person is considered normal, with a given probability reliability such event -0.95 has been established. To verify the effectiveness of the proposed method, algorithms for estimating the sensorimotor reaction time of a small UAV operator in three modes have been synthesized and the corresponding software that implements the proposed algorithms has been developed.

Conclusions. The criteria for evaluating the sensorimotor reaction time for UAV operator to a visual stimulus using specialized software were substantiated. This allowed the previous PPS training candidates to take into account the requirements to the motor skills of the small UAV operator and the specificity his movements. The conducted experiments confirmed the validity of decisions made. Prospects for further research may include expansion of testing modes with justification for appropriate evaluation criteria.

KEYWORDS: evaluation criteria, small UAV operator, sensorimotor reaction time, distribution density.

\author{
ABBREVIATIONS \\ $\mathrm{PC}$ is a personal computer; \\ PPS is a professional psychological selection; \\ UAV is an unmanned aerial vehicle; \\ USB is an Universal Serial Bus.
}

\section{NOMENCLATURE}

$a_{m}$ is a value of the minimal sensorimotor reaction time operators in $m$-th testing mode;

$b_{m}$ is a value of maximum allowable operator's sensorimotor reaction time in $m$-th testing mode;

$f(t)$ is a distribution density of average reaction time duration;

$f_{m}(t)$ is a distribution density of average reaction time duration in $m$-th testing mode;

$K$ is a coefficient on 9-th point scale;

$m$ is a number of evaluation modes of sensorimotor reaction, $m=3$;

(C) Vakaliuk T. A., Pilkevych I. A., Tokar A. M., Loboda R. I., 2021

DOI 10.15588/1607-3274-2021-2-19 $m_{t}$ is a mathematical expectation of mean sensorimotor reaction time estimates;

$n$ is a number of people being tested;

$t$ is a time interval;

$t_{m n}$ is a sensorimotor reaction time of $n$-th operator in $m$-th testing mode;

$T_{N}$ is a normative operator's sensorimotor reaction time;

$T_{m}$ is a measured operator's sensorimotor reaction time;

$X(t)$ is a number of people whose reaction time falls within the time interval $t$;

$\sigma$ is a standard deviation of mean sensorimotor reaction time estimates;

$\hat{\sigma}$ is an estimation of standard deviation of mean sensorimotor reaction time estimates. 


\section{INTRODUCTION}

To date, the list of industries where UAVs are used is rapidly expanding. The effectiveness of their application depends both on the technical characteristics the UAV and on the actions operators. Today, methods research technical systems allow successfully establishing the laws of occurrence device failures and methods of their forecasting. This makes it possible to design and manufacture optimal devices, of which the onboard equipment for UAVs is completed.

At the same time, it has been established that one of the causes reduced effectiveness of small UAV application is insufficient operator professional reliability [1-5], which is understood as the reliability, accuracy and timeliness their actions aimed at performing the task during UAV control [6]. Operator's professional reliability directly depends on his psycho-physiological qualities, high manifestations which is one factors of operators' reliable work $[7,8]$. The main direction to ensure the necessary level of reliability operators is the formation of their professional suitability, which is understood as the availability human psychophysiological and psychological properties, which correspond to a particular profession and provide sufficient efficiency of professional activity $[6,7]$. The process of professional suitability formation involves creating a system for professional selection and training for a certain profile of operator activity (methods, tools, programs, criteria, simulators and the like) $[6,9]$. An important component in this system is the professional psychological selection (PPS) of candidates for training, which consists in carrying out a set to ensure the quality selection the candidates, by assessing the compliance of the level development necessary psychophysiological qualities and personality properties with the requirements of professional activity $[10,11]$. One of main stages PPS small UAV operators is evaluation evaluation of their sensorimotor reactions, which involves the use specialized complex (hardware, hardware-software, software). The efficiency of this process largely depends on the selected criteria for evaluating the obtained reaction time on the small UAV operator.

The object of study is the process evaluation of sensorimotor reaction time a small UAV operator.

The subject of study is the method of evaluating criteria for the sensorimotor reaction time of a small UAV operator.

The purpose of the work is to improve PPS quality of small UAV operators by evaluating their sensorimotor reaction time.

\section{PROBLEM STATEMENT}

To estimate the level of operator fatigue for different activity profiles, their readiness for action and fitness for professional activity, the results of sensomotor reaction duration measurement (a single discrete movement an operator to the appearance (cessation of action) a stimulus) are used [12-19]. The use methods for (C) Vakaliuk T. A., Pilkevych I. A., Tokar A. M., Loboda R. I., 2021 DOI 10.15588/1607-3274-2021-2-19 measuring the duration is based on the fact that each elementary motor response is the result of a complex interaction different human brain systems. Reaction duration is a manifestation of both individual peculiarities a nervous system and a person's state at a given moment. Depending on the profile of professional activity, the purpose and conditions of the study, the type of reaction being monitored, different complexes (devices) for evaluating the operator's sensorimotor reactions are used. At the same time appropriate methods of processing and evaluating measurement results are used $[14,15]$.

The development for computing technology has led to the use specialized software products for the evaluation of sensorimotor reactions operators for different activity profiles, in particular UAV operators $[16,19]$. The use such systems involves performing a certain action using the keyboard, manipulator, external devices in response to stimuli that are displayed on the monitor.

Taking into account current trends, we will evaluate the sensorimotor reaction time of small UAV operators, according to the scheme, which is shown in Fig. 1.

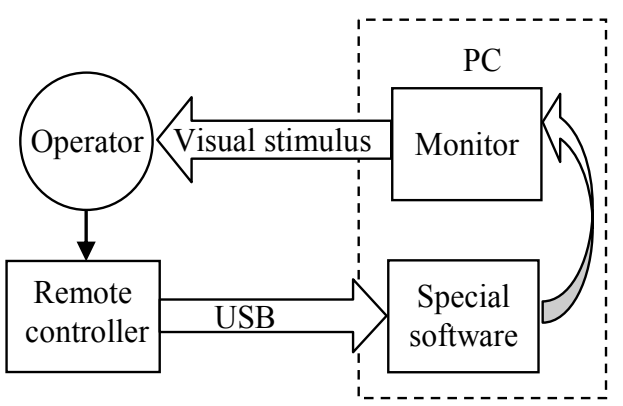

Figure 1 - The scheme for evaluating the time of sensorimotor reactions by small UAV operators

The result of measuring the time of sensorimotor reactions is an amount of data:

$$
\begin{aligned}
& {\left[t_{11}, t_{12}, \ldots, t_{1 n}\right],} \\
& {\left[t_{21}, t_{22}, \ldots, t_{2 n}\right],} \\
& {\left[t_{m 1}, t_{m 2}, \ldots, t_{m n}\right] .}
\end{aligned}
$$

In this case, the task of justification criteria for estimating the sensorimotor reaction time the small UAV operator is to find such values $a_{m}$ i $b_{m}$, for which the condition is met

$$
\int_{a_{m}}^{b_{m}} f_{m}(t) d t=0.95
$$

\section{REVIEW OF THE LITERATURE}

As yet, little is known about the specific demands on operating UAV personnel. The different unmanned aerial systems that are currently in use differ in operational concepts and control systems [11].

Analysis of published shows that to assess the required abilities and skills from cognitive, psychomotor, physical, 
sensory and interactive/social domains needs to take into account the specifics of small UAV operator activity.

Thus, in the study the factors that affect the stable work and fatigue of the operator several UAV used the task of observing signals and counting symbols for 2 -th hours. The subjective states were assessed with the Dundee Stress State Questionnaire [17]. This approach requires a lot of time to conduct the study, process and evaluate the results.

The psychomotor reaction time operator MQ-1 Predator was evaluated using the MicroCog test. The analyses in this study were generated using SAS software, version 9.3 (SAS Institute, Cary, NC), taking into account daily assessments and dividing into two groups based on threshold. To determine which aptitudes were predictive of high performers, stepwise binary logistic regressions were used to retain predictor effects titrating from $p<0.05$ to $p<0.30$, by incremental units of 0.05 [16].

When evaluating psychomotor reactions for operators of military UAVs, the specifics of activities (UAV operators and sensor/payload operators), concepts of operation and control system of UAVs, in particular Heron 1 in the German Air Force and LUNA, KZO and Aladin in the German Army [11].

Consequently, it is possible to take into account the specifics a small UAV functioning when evaluating the operator's sensorimotor reaction time, by selecting and justifying the appropriate criteria. It is important that the criterion can be applied to estimate reactions, which are measured on the same complex, which was used to obtain output data for its justification. This will allow for static errors that may differ between complexes (stimulus output time, inertia of hardware levers, duration of response arrival, and the like).

\section{MATERIALS AND METHODS}

The most common approach to substantiating the criteria and standards for evaluating sensorimotor reactions is the accumulation for statistical material and its mathematical mathematical processing [16, 11, 1820]. To get the necessary data, we developed a program complex in LabVIEW, which allows estimating sensorimotor reaction time in the modes: skill development, under obstacle conditions, and under conditions of skill rearrangement. The program provides formation of visual stimuli and displaying them on the PC monitor depending on the testing mode, reading and processing of hardware data, processing of measurement results and archiving of obtained data. The appearance of the program working window is shown on Fig. 2.

In order to substantiate the criterion for evaluating the sensorimotor reaction time by a small UAV operator, a control group of 67 students was selected. It should be noted that the students had no skills of UAV piloting. As a result of testing the selected persons with the help of the developed complex, statistical data was obtained concerning the average time of sensorimotor reactions of each person in conditions a skill, obstacles, rearrangement skill. The sensorimotor reaction time is a random continuous value that can take a value from a certain interval. In order to establish a norm against which to compare the values obtained and decide on the suitability of candidates for study, let us estimate the numerical characteristics of the data obtained in each of the three modes.

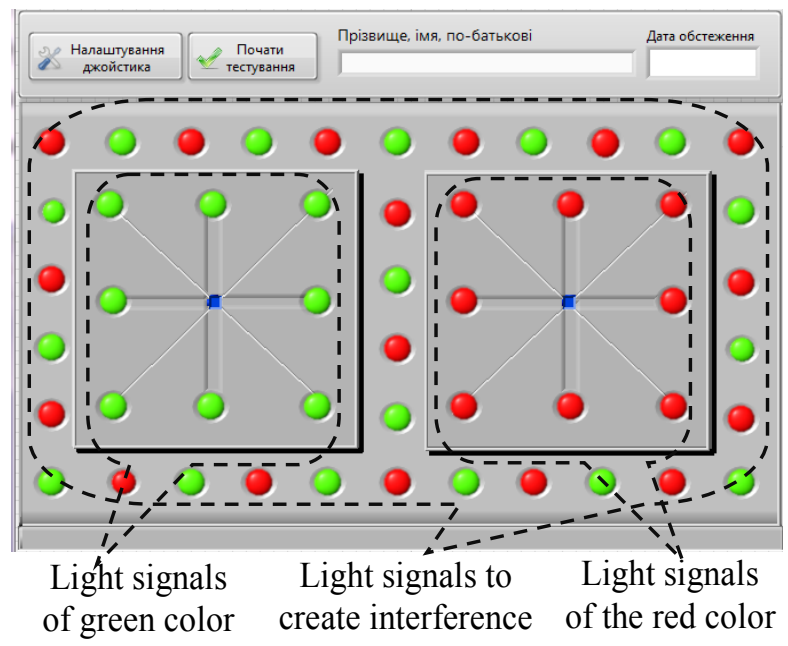

Figure 2 - The external appearance a working window

To this end, let us construct statistical series for the three evaluation modes (Table 1). To do this, divide the entire range of obtained values into intervals and count the number $X_{i}$, alues that fell into each $i$-th interval [21].

On the basis these statistical series, histograms for the distribution of the duration of the average reaction time (Fig. 3).

Table 1 - Statistical series of obtained values

\begin{tabular}{|c|c|c|c|}
\hline$t, \mathrm{~s}$ & $\begin{array}{c}X(t) \text { in the } \\
\text { conditions of } \\
\text { the skill } \\
\text { development, } \\
\text { the person }\end{array}$ & $\begin{array}{c}X(t) \text { in the } \\
\text { conditions of } \\
\text { disadvantages, } \\
\text { the person }\end{array}$ & $\begin{array}{c}X(t) \text { in the } \\
\text { context of skill } \\
\text { restructuring, } \\
\text { the person }\end{array}$ \\
\hline $0.8-0.9$ & 2 & 1 & 5 \\
\hline $0.9-1.0$ & 1 & 1 & 5 \\
\hline $1.0-1.1$ & 11 & 4 & 7 \\
\hline $1.1-1.2$ & 17 & 9 & 7 \\
\hline $1.2-1.3$ & 10 & 13 & 8 \\
\hline $1.3-1.4$ & 6 & 11 & 4 \\
\hline $1.4-1.5$ & 9 & 8 & 5 \\
\hline $1.5-1.6$ & 3 & 4 & 4 \\
\hline $1.6-1.7$ & 4 & 7 & 6 \\
\hline $1.7-1.8$ & 1 & 7 & 2 \\
\hline $1.8-1.9$ & 1 & 1 & 1 \\
\hline $1.9-2.0$ & 0 & 1 & 1 \\
\hline $2.0-2.1$ & 0 & 0 & 1 \\
\hline $2.1-2.2$ & 1 & 0 & \\
\hline $2.2-2.3$ & 1 & 0 & \\
\hline & & & 10 \\
\hline
\end{tabular}



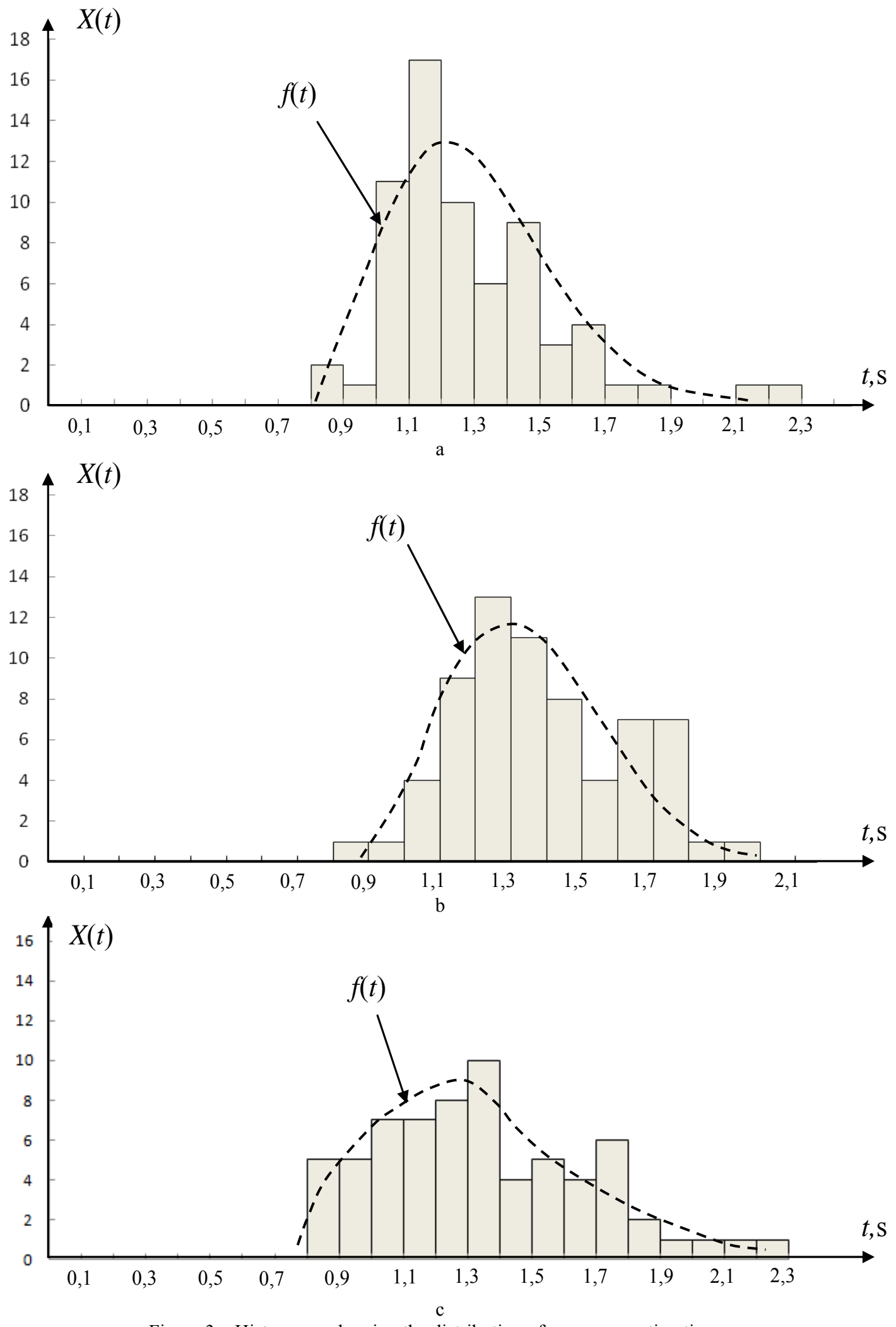

Figure 3 - Histograms showing the distribution of average reaction times:

$\mathrm{a}$ - in conditions of skill development; $\mathrm{b}$ - in conditions of obstacles; $\mathrm{c}$ - in conditions of skill reconstruction 
In the given statistical distributions there is an error of representativeness. That is why during processing this statistical material there was a decoupled task on statistical series alignment, which consisted in selection of theoretical distribution curve for each series, which will display only essential features of statistical material and not randomness, connected with insufficient volume of experimental data [21]. For this purpose, the histogram of the distribution was approximated by a fourth-degree polynomial in Microsoft Office Excel. As a result, we obtained theoretical densities of the distribution of the average reaction time $-f(t)$ (see Fig. 3).

A priori, most researchers assume that the distribution of sensorimotor reaction times is close to normal. However, the obtained plot for the density distribution of the mean reaction time has an asymmetry, which agrees with numerous experimental works, in which it is shown that the distribution of reaction times has a significant positive asymmetry in most cases $[18,20,22]$. This phenomenon has a convincing explanation: reaction times are characterized by the presence a rigid lower limit, determined by the physiological capabilities of the person and the complex on which the study is conducted, while the upper limit varies over a wide range and is usually associated with the features tested [18].

Determination of the distribution law with the density values that are presented in Fig. 3 and the calculation its parameters requires additional research.Therefore, taking into account the need to determine the standard for the upper limit of measured values only, in our further calculations we restrict ourselves to the data that describe the right branch of the distribution density relative to its mode, to the data describing the right branch of distribution density relative to its mode. With increasing of observations, this branch will approach corresponding branch of normal law distribution density [21] with mathematical expectation $m_{t}$, which is equal to the modality of the distribution. In this case formula (1) it will look like

$$
\int_{m_{t}}^{T_{N}} f_{m}(t) d t=0.48
$$

Probability of a random variable distributed according to the normal law in the interval $m_{t}+T_{N}$ will have a value of 0,48 if

$$
T_{N}=m_{t}+2 \sigma \text {. }
$$

To obtain an estimate of the standard deviation we use the expression [21]

$$
\hat{\sigma}=\sqrt{\frac{\sum_{i=1}^{n}\left(X_{i}-m_{t}\right)^{2}}{n-1}} .
$$

(C) Vakaliuk T. A., Pilkevych I. A., Tokar A. M., Loboda R. I., 2021 DOI 10.15588/1607-3274-2021-2-19
Using the level statistical data, which are described by the theoretical graph of the density distribution of the average reaction time, we performed calculations for expressions (2), (3) and obtained standards for the upper limit of measured values of the duration of sensorimotor reactions by small UAV operators in conditions: skill development, obstacles, skill restructuring (Table 2).

Table 2 - Results of the calculations

\begin{tabular}{|c|c|c|c|}
\hline \multirow{2}{*}{ indicator } & \multicolumn{3}{|c|}{ Values of the indicators } \\
\cline { 2 - 4 } & $\begin{array}{c}\text { in the } \\
\text { development } \\
\text { of a skill, } \mathrm{s}\end{array}$ & $\begin{array}{c}\text { in the face of } \\
\text { obstacles, } \mathrm{s}\end{array}$ & $\begin{array}{c}\text { in the context } \\
\text { of skill } \\
\text { restructuring, } \mathrm{s}\end{array}$ \\
\hline$m_{t}$ & 1.22 & 1.33 & 1.30 \\
\hline$\hat{\sigma}$ & 0.33 & 0.29 & 0.4 \\
\hline$T_{N}$ & 1.88 & 1.91 & 2.10 \\
\hline
\end{tabular}

\section{EXPERIMENTS}

Based on the results obtained, the sensorimotor reaction time for candidates to study the appropriate training program and to master the specialty UAV operator in the PPS was evaluated. It should be noted that candidates were pre-selected for the level of general training, motivation to study, experience in UAV piloting. The total number of persons in the training groups was 208 persons.

During the evaluation, the developed software package was used (see Fig. 1). As the hardware that provides specific movements in response to stimuli was used a UAV control panel, which is connected to the PC through the USB interface. The task of the candidates was to respond as quickly as possible with movements using the control levers to the flashes of light signals that are located in the program window. The light signals light up until the right movement was made.

In the right square there are 8-th red light signals that need movements of the right arm control panel. In the left square there are eight green light signals, which need to perform movements with the left manipulator of the control panel.

When evaluating the sensorimotor reactions by small UAV operators under conditions a skill is developed, the light signals that are located in the squares light up. The light signals can be extinguished by making a movement, with the appropriate remote control arm, in the direction the light signals that lit up.

When evaluating the sensorimotor reactions by small UAV operators under obstacle conditions, together with the light signals that are located in the squares, the light signals located on the outer perimeter, which are designed to create obstacles (distracting visual signals), are lit. It is possible to extinguish the light signals by making a movement, with the appropriate remote control arm, in the direction of the light bulb, which is lit in the squares. 
The peculiarity in evaluating sensorimotor reactions of small UAV operators in conditions of skill rearrangement is the need to make mirror movements by manipulators of the remote control in response to the ignition light signals. That is, when red light signals, which are located in the right square, ignite, it is necessary to respond with movements of the left manipulator, when green light signals, which are located in the left square, ignite, it is necessary to respond with movements of the right manipulator.

In each test mode 50-th flashes are performed. Hardware calibration is performed before testing begins. Evaluation results are recorded in a text file that can be reviewed in a Microsoft Office Excel or Word environment.

\section{RESULTS}

According to the results of the experiment, the distribution of candidates by time of testing is plotted, which is shown in Fig. 4.

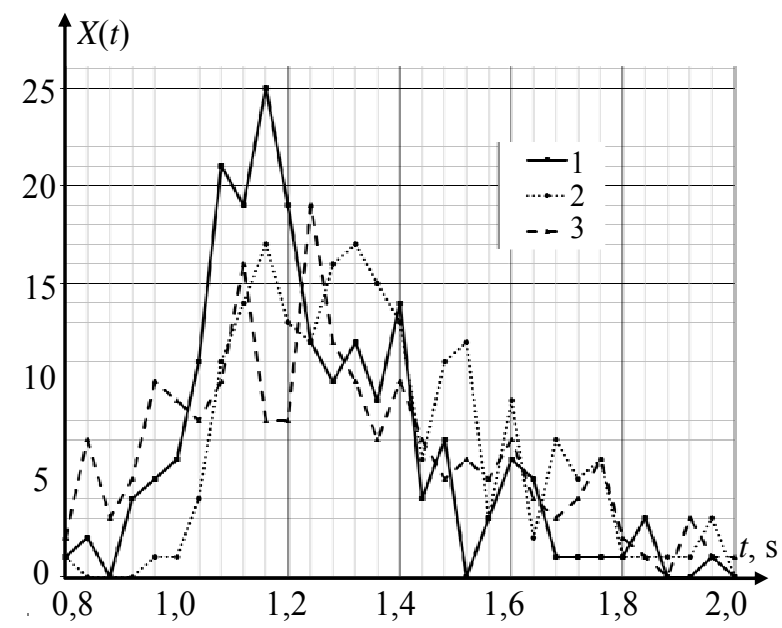

Figure 4 - Distribution of candidates by time of testing: 1 - in conditions of skill development; 2 - in conditions of obstacles; $3-$ in conditions of skill restructuring

In order to obtain an integral assessment for candidates' suitability for study, the results obtained from all tests, including sensorimotor reaction time, were reduced to a single 9-th point scale. For this purpose, the coefficient was calculated by the expression

$$
K=10 \frac{T_{N}}{T_{m}} .
$$

The transition to the 9-th grade scale was carried out according to Table 3 .

Table 3 - Grading standards with a 9-point scale

\begin{tabular}{|c|l|l|l|l|l|l|l|l|c|}
\hline score & 1 & 2 & 3 & 4 & 5 & 6 & 7 & 8 & 9 \\
\hline$K$ & $\leq 7$ & 7 & 8 & 9 & 10 & 11 & 12 & 13 & $\geq 13$ \\
\hline
\end{tabular}

C) Vakaliuk T. A., Pilkevych I. A., Tokar A. M., Loboda R. I., 2021

DOI 10.15588/1607-3274-2021-2-19
The final score was derived as the arithmetic mean value of the scores obtained in the three test modes. If a fractional number was obtained, it was rounded to a whole number. Candidates who scored less than 5-th points in total were considered unfit for further study, there were 4 such out of 208 examinees. According to the results of other tests (spatial operation of geometrical grudges; memory for visual grudges; long-term concentration of attention under difficult conditions, responsibility and neatness) these persons turned out to be fit for study. According to the results from the study, they successfully passed the examinations. According to the instructors' evaluations, the marked persons had a slightly harder time mastering practical skills from piloting.

\section{DISCUSSION}

The results show that those who were pre-selected for the level a general training, motivation to study got better indicators of sensorimotor reaction time, in comparison with the control group. At the same time, we can conclude that the sensorimotor reaction time cannot be regarded as the only indicator of candidates' suitability for the training program for small UAV operators. It is reasonable to use reaction time estimation as an additional factor during PPS. The obtained distribution densities of the average reaction time duration need additional study.

It is necessary to investigate the causes of the nature of failures at certain hour intervals in the conditions of obstacles and skill restructuring. Based on the results of the accumulation of statistical material, it is advisable to refine the criteria for evaluating the sensorimotor reaction time of a small UAV operator.

In further research, it is advisable to increase the number of criteria for evaluating the operator's sensorimotor reaction time. This will make it possible to introduce additional levels of candidate suitability: suitable, suitable with restriction, conditionally suitable, unsuitable, and so on.

\section{CONCLUSIONS}

The methods of justification criteria for evaluating the sensorimotor reaction time of a small UAV operator have been further developed in this work. This allowed improving the quality of PPS of UAV operators.

For the first time, specialized software has been developed, the implementation of which allowed to increase the efficiency and simplify the procedure for evaluating study candidates. The proposed approach ensured that the peculiarities involved in the functioning the small UAV and the specifics of the operator's nimble movements were taken into account.

Improved the process of integral assessment the candidates' suitability for training according to the results obtained by passing many tests, by reducing the obtained estimates the sensorimotor reaction time of the small UAV operator to a single scale. 


\section{ACKNOWLEDGEMENTS}

The work is supported scientific research project of Zhytomyr military institute named after S. P. Korolov "Development of a hardware and software system for evaluating sensorimotor reactions of unmanned aerial vehicle operators" (state registration number 0118U000023)

\section{REFERENCES}

1. Williams K.W. Human Factors Implications of Unmanned Aircraft Accidents: Flight-Control Problems, Human Factors of Remotely Operated Vehicles (Advances in Human Performance and Cognitive Engineering Research), 2006, Vol. 7, pp. 105116. DOI: 10.1016/S1479-3601(05)07008-6

2. Wiegmann D., Shappell S. A human error approach to aviation accident analysis: the Human Factors Analysis and Classification System. Burlington, VT, Ashgate, 2003, 165 p. DOI: $10.4324 / 9781315263878-3$

3. Goodrich M. A., Cummings M. L. Human Factors Perspective on Next Generation Unmanned Aerial Systems, Handbook of Unmanned Aerial Vehicles, Springer-Verlag, 2015, pp. 24052423. DOI: 10.1007/978-90-481-9707-1 23

4. Oncu M., Yildiz S. An analysis of human causal factors in unmanned aerial vehicle (UAV) accidents. alifornia, Monterey, December 2014, 91 p. DOI: 10.21236/ada620843

5. Qi S., Wang F., Jing L. Aircraft System Pilot/Operator Qualification Requirements and Training Study, MATEC Web Conference: Second International Conference on Mechanical, Material and Aerospace Engineering, 2MAE, 2018, Vol. 179, 03006. DOI: $10.1051 /$ matecconf $/ 201817903006$

6. Havlikova M., Jirglb M., Bradac Z. Human Reliability in ManMachine Systems, Procedia Engineering, 2015, Vol. 100, pp. 1207-1214. DOI: 10.1016/j.proeng.2015.01.485

7. Chung W. K. Reliability evaluation of a human operator under various levels of stress, Microelectronics Reliability, 1991, Vol. 31, № 6, pp. 1251-1255. DOI: 10.1016/0026-2714(91)90315-X

8. Petrov A., Volodina K., Belyaevam T. The role of the psychophysiological characteristics of a person in his professional development, Education and Self Development, 2019. Vol. 14, No. 4, pp. 63-71. DOI: $10.26907 /$ esd14.4.06

9. Hryshchenko Y. Reliability problem of ergatic control systems in aviation, Methods and Systems of Navigation and Motion Control (MSNMC), Fourth International Conference. Kiev, 1820 October 2016, pp. 126-129. DOI $10.1109 /$ msnmc.2016.7783123

10. Lancaster R., Baseman E. Smolinski L. A quality improvement project: Defining and operationalizing a holistic admission selection policy, Journal of Professional Nursing, 2020, Vol. 36, No. 4, pp. 259-263. DOI: 10.1016/j.profnurs.2020.01.003

11. Melcher W., Neumann M., Eißfeldt H., Schwab A. Cognitive and psychomotor requirements for operators of military UAS, 61st Conference of the International Military Testing Association in Tallinn, 7-11 October 2019, 11 p.
12. Ermakov A. Simple and Complex Sensomotor Reaction for Choice when Teaching Protection Against Armed Attacker, First International Volga Region Conference on Economics, Humanities and Sports (FICEHS 2019), 18 January 2020, pp. 772-774. DOI: 10.2991/aebmr.k.200114.185

13. Tadema J., Theunissen E. A concept for UAV operator involvement in airborne conflict detection and resolution, 27th Digital Avionics Systems Conference, St. Paul, MN, USA, 26-30 October 2008, pp. 4.C.1-1-4.C.1-12. DOI 10.1109/DASC.2008.4702829

14. Chappelle W., Tran N., Thompson W., Goodman T., Hyde K. Intelligence and neuropsychological aptitude testing of U.S. Air Force MQ-1 Predator pilot training candidates, Wright-Patterson AFB (OH): U.S. Air Force School of Aerospace Medicine, 2012. Technical Report AFRL-SA-WP-TR-2013-0003. DOI: 10.21236/ada577826

15. Chappelle W., Heerema B., Thompson W. Factor analysis of computer-based Multidimensional Aptitude Battery-Second Edition intelligence testing from rated U. S. Air Force pilots. Wright-Patterson AFB (OH): U.S. Air Force School of Aerospace Medicine, 2012, Technical Report AFRL-SA-WP-TR-2013-0005. DOI: $10.21236 /$ ada583710

16. Chappelle W., Goodman T., Swearingen J., Thompson W. A Preliminary Investigation into Cognitive Aptitudes Predictive of Overall MQ-1 Predator Pilot Qualification Training Performance, Wright-Patterson AFB (OH): U.S. Air Force School of Aerospace Medicine, 2015. Technical Report AFRL-SA-WP-SR-2015-0025, $14 \mathrm{p}$.

17. Ryan W., Matthews G., Lin J., Szalma J., Calhoun G., Funke G., Chiu C-Y., Ruff H. Vigilance and Automation Dependence in Operation of Multiple Unmanned Aerial Systems (UAS): A Simulation Study, Hum Factors, May 2019, Vol. 61, No. 3, pp. 488-505. DOI: 10.1177/0018720818799468

18. Kukushkin Ju., Ajvazjan S. Metodika avtomatizirovannoj obrabotki upravljajushhih dvizhenij operatora $\mathrm{v}$ prikladnyh issledovanijah nadezhnosti jergaticheskih sistem, Kibernetika $i$ programmirovanie, 2018, No. 5, pp. 15-23. DOI: 10.25136/2306-4196.2018.5.1817

19. Gusev D., Klimov R. Programmnyj kompleks apriornogo ocenivanija pokazatelej kachestva professional'noj dejatel'nosti operatora jergaticheskoj sistemy, Programmnye sistemy vychislitel'nye metody, 2015, No. 4. pp. 374-389. DOI: 10.7256/2305-6061.2015.4.17965

20. Ignatova Y. Makarova I., Yakovleva K., Aksenova A. Visualmotor reactions as an indicator of CNS functional state, Ulyanovsk Medico-biological Journal, 2019, No. 3, pp. 38-51. DOI: 10.34014/2227-1848-2019-3-38-51

21. Werner L. Probability Theory. De Gruyter Textbook, 2016, 395 p. DOI: 10.1515/9783110466195

22. Kulakov A. Osobennosti prostoj psihofiziologicheskoj reakcii, Fiziologija cheloveka, 2018, Tom 44, No. 4, pp. 60-66. DOI: $10.1134 / \mathrm{s} 0131164618040069$

Received 28.01.2021. Accepted 15.05.2021.

\section{УДК 004.67: 37.042.2}

\section{КРИТЕРІЇ ОЦНЮЮАННЯ ЧАСУ СЕНСОМОТОРНОЇ РЕАКЦІЇ ОПЕРАТОРА МАЛИХ БПЛА}

Вакалюк Т. А. - доктор педагогічних наук, професор, професор кафедри інженерії програмного забезпечення, Державний університет «Житомирська політехніка», Житомир, Україна.

Пількевич І. А. - доктор технічних наук, професор, професор кафедри комп’ютерних інформаційних технологій, Житомирський військовий інститут імені С. П. Корольова, Житомир, Україна.

Токар А. М. - кандидат технічних наук, начальник науково-дослідного відділу, Житомирський військовий інститут імені С. П. Корольова, Житомир, Україна 
Лобода Р. І. - науковий співробітник науково-дослідного відділу, Житомирський військовий інститут імені С. П. Корольова, Житомир, Україна.

\section{АНОТАЦІЯ}

Актуальність. Стрімкий розвиток науки та техніки зумовлює значне розширення сфер застосування БпЛА різного призначення. Запорукою ефективного використання БпЛА $є$ якісна підготовка операторів, важливим елементом якої $є$ професійний психологічний відбір (ППВ) кандидатів, зокрема, оцінювання їх сенсомоторних реакцій. Це можна забезпечити шляхом вибору та обгрунтування відповідних критеріїв.

Мета. Метою роботи є обгрунтування критеріїв оцінювання часу сенсомоторних реакцій оператора малих БпЛА шляхом аналізу щільності розподілу статистичних даних.

Метод. Запропоновано метод, що дозволив визначити критерії оцінювання часу сенсомоторних реакцій оператора малих БпЛА на основі накопичення статистичного матеріалу та його математичного оброблення за результатами проведення натурного експерименту. Метод дозволяє оцінити числові характеристики розподілу тривалості середнього часу реакції у трьох режимах: вироблення навички, в умовах перешкод, в умовах перебудови навички та отримати узагальнену оцінку. Вдалося, шляхом аналізу випадкових неперервних величин, що приймають значення 3 деякого проміжку значень, встановити нормативи, 3 якими порівнюються отримані значення часу сенсомоторної реакції оператора малих БпЛА та приймається рішення щодо їх придатності до навчання.

Результати. У роботі отримано статистичні ряди для режимів оцінювання: вироблення навички, в умовах перешкод, в умовах перебудови навички. Для наочного представлення рядів побудовано відповідні гістограми розподілу тривалості середнього часу реакції. 3 метою усунення помилки репрезентативності здійснено вирівнювання статистичних рядів шляхом підбору для кожного ряду теоретичної кривої розподілу, що відображає лише суттєві риси статистичного матеріалу. Для цього здійсненна апроксимація гістограми розподілу поліномом четвертого ступеня. Встановлено інтервал теоретичної щільності розподілу, попадання в який часу сенсомоторної реакції довільної особи вважається нормою, при задані ймовірності достовірності такої події - 0,95. Для перевірки дієвості запропонованого методу синтезовано алгоритми оцінювання часу сенсомоторної реакції оператора малих БпЛА у трьох режимах та розроблено відповідне програмне забезпечення, що реалізує запропоновані алгоритми.

Висновки. Обгрунтовано критерії оцінювання часу сенсомоторної реакції оператора БпЛА на зоровий подразник 3 використанням спеціалізованого програмного забезпечення. Це дозволило проводити попередній ППВ кандидатів на навчання 3 урахуванням вимог до моторики оператора малих БпЛА і специфіки його рухів. Проведені експерименти підтвердили обгрунтованість прийнятих рішень. Перспективи подальших досліджень можуть включати розширення режимів тестування з обгрунтуванням відповідних критеріїв оцінювання.

КЛЮЧОВІ СЛОВА: критерії оцінювання, оператор малих БпЛА, час сенсомоторної реакції, щільність розподілу.

УДК 004.67: 37.042 .2

\section{КРИТЕРИИ ОЦЕНКИ ВРЕМЕНИ СЕНСОМОТОРНОЙ РЕАКЦИИ ОПЕРАТОРА МАЛЫХ БПЛА}

Вакалюк Т. А. - доктор педагогических наук, профессор, профессор кафедры инженерии программного обеспечения, Государственный университет «Житомирская политехника», Житомир, Украина.

Пількевич I. А. - доктор технических наук, профессор, профессор кафедры компьютерных информационных технологий, Житомирский военный институт имени С. П. Королева, Житомир, Украина.

Токар А. Н. - кандидат технических наук, начальник научно-исследовательского отдела, Житомирский военный институт имени С. П. Королева, Житомир, Украина.

Лобода Р. И. - научный сотрудник научно-исследовательского отдела, Житомирский военный институт имени С. П. Королева, Житомир, Украина.

Актуальность. Стремительное развитие науки и техники приводит к значительному расширению сфер применения БпЛА различного назначения. Залогом эффективного использования БпЛА является качественная подготовка операторов, важным элементом которой является профессиональный психологический отбор (ППО) кандидатов, в частности, оценка их сенсомоторных реакций. Это можно обеспечить путем выбора и обоснования соответствующих критериев.

Цель. Целью работы является обоснование критериев оценки времени сенсомоторных реакций оператора малых БпЛА путем анализа плотности распределения статистических данных.

Метод. Предложен метод, который позволил определить критерии оценки времени сенсомоторных реакций оператора малых БпЛА на основе накопления статистического материала и его математической обработки по результатам проведения натурного эксперимента. Метод позволяет оценить числовые характеристики распределения продолжительности среднего времени реакции в трех режимах: выработки навыка, в условиях помех, в условиях перестройки навыка и получить обобщенную оценку. Удалось, путем анализа случайных непрерывных величин, принимающих значения из некоторого промежутка значений, установить нормативы, с которыми сравниваются полученные значения времени сенсомоторной реакции оператора малых БпЛА и принимается решение об их пригодности к обучению.

Результаты. В работе получены статистические ряды для режимов оценки: выработки навыка, в условиях помех, в условиях перестройки навыка. Для наглядного представления рядов построены соответствующие гистограммы распределения продолжительности среднего времени реакции. С целью устранения ошибки репрезентативности осуществлено выравнивание статистических рядов путем подбора для каждого ряда теоретической кривой распределения, которая отражает только существенные черты статистического материала. Для этого осуществлена аппроксимация гистограммы распределения полиномом четвертой степени. Установлено интервал теоретической плотности распределения, попадание в который времени сенсомоторной реакции произвольного лица считается нормой, при заданной вероятности

(C) Vakaliuk T. A., Pilkevych I. A., Tokar A. M., Loboda R. I., 2021

DOI 10.15588/1607-3274-2021-2-19 
достоверности такого события - 0,95. Для проверки действенности предложенного метода синтезированы алгоритмы оценки времени сенсомоторной реакции оператора малых БпЛА в трех режимах и разработано соответствующее программное обеспечение, реализующее предложенные алгоритмы.

Выводы. Обоснованы критерии оценки времени сенсомоторной реакции оператора БпЛА на зрительный раздражитель с использованием специализированного программного обеспечения. Это позволило проводить предварительный ППО кандидатов на обучение с учетом требований к моторике оператора малых БпЛА и специфике его движений. Проведенные эксперименты подтвердили обоснованность принимаемых решений. Перспективы дальнейших исследований могут включать расширение режимов тестирования с обоснованием соответствующих критериев оценки.

КЛЮЧЕВЫЕ СЛОВА: критерии оценки, оператор малых БпЛА, время сенсомоторной реакции, плотность распределения.

\section{ЛІТЕРАТУРА / ЛИТЕРАТУРА}

1. Williams K.W. Human Factors Implications of Unmanned Aircraft Accidents: Flight-Control Problems / K. W. Williams // Human Factors of Remotely Operated Vehicles (Advances in Human Performance and Cognitive Engineering Research). 2006. - Vol. 7. - P. 105-116. DOI: 10.1016/S14793601(05)07008-6

2. Wiegmann D. A human error approach to aviation accident analysis: the Human Factors Analysis and Classification System / D. Wiegmann, S. Shappell. - Burlington, VT: Ashgate, 2003. - 165 p. DOI: $10.4324 / 9781315263878-3$

3. Goodrich M. A. Human Factors Perspective on Next Generation Unmanned Aerial Systems / M. A. Goodrich, M. L. Cummings // Handbook of Unmanned Aerial Vehicles, Springer-Verlag. - 2015. - P. 2405-2423. DOI: 10.1007/97890-481-9707-1 23

4. Oncu M. An analysis of human causal factors in unmanned aerial vehicle (UAV) accidents / M. Oncu, S. Yildiz. California, Monterey, December 2014. - 91 p. DOI: 10.21236/ada620843

5. Qi S. Aircraft System Pilot/Operator Qualification Requirements and Training Study / S. Qi, F. Wang, L. Jing // MATEC Web Conference: Second International Conference on Mechanical, Material and Aerospace Engineering, 2MAE. -

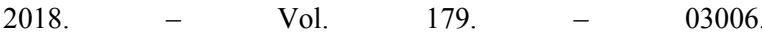
DOI: $10.1051 /$ matecconf/201817903006

6. Havlikova M. Human Reliability in Man-Machine Systems / M. Havlikovaa, M. Jirglb, Z. Bradac // Procedia Engineering. 2015. - Vol. 100. - $\quad$ P. 1207-1214. DOI: 10.1016/j.proeng.2015.01.485

7. Chung W. K. Reliability evaluation of a human operator under various levels of stress / W. K. Chung // Microelectronics Reliability. - 1991. - Vol. 31, № 6. - P. 1251-1255. DOI: 10.1016/0026-2714(91)90315-X

8. Petrov A. The role of the psycho-physiological characteristics of a person in his professional development / A. Petrov, K. Volodina, T. Belyaevam // Education and Self Development. - 2019. - Vol. 14, № 4. - P. 63-71. DOI $10.26907 /$ esd14.4.06

9. Hryshchenko Y. Reliability problem of ergatic control systems in aviation / Y. Hryshchenko // Methods and Systems of Navigation and Motion Control (MSNMC) : Fourth International Conference , Kiev, 18-20 October 2016. - P. 126129. DOI: $10.1109 / \mathrm{msnmc} .2016 .7783123$

10. Lancaster R. A quality improvement project: Defining and operationalizing a holistic admission selection policy / R.Lancaster E.Baseman L.Smolinski // Journal of Professional Nursing. - 2020. - Vol. 36, № 4. - P. 259-263. DOI: 10.1016/j.profnurs.2020.01.003

11. Cognitive and psychomotor requirements for operators of military UAS / [W. Melcher, M. Neumann, H. Eißfeldt, A. Schwab]. - 61st Conference of the International Military Testing Association in Tallinn, 7-11 October 2019. - 11 p.
12. Ermakov A. Simple and Complex Sensomotor Reaction for Choice when Teaching Protection Against Armed Attacker A. Ermakov // First International Volga Region Conference on Economics, Humanities and Sports (FICEHS 2019), 18 January 2020. - P. 772-774. DOI: 10.2991/aebmr.k.200114.185

13. Tadema J. A concept for UAV operator involvement in airborne conflict detection and resolution / J. Tadema, E. Theunissen // 27th Digital Avionics Systems Conference, St. Paul, MN, USA, 26-30 October 2008. - P. 4.C.1-1-4.C.1-12. DOI: $10.1109 /$ DASC.2008.4702829

14. Chappelle W. Intelligence and neuropsychological aptitude testing of U.S. Air Force MQ-1 Predator pilot training candidates. / [W. Chappelle, N. Tran, W. Thompson et al] // Wright-Patterson AFB (OH): U.S. Air Force School of Aerospace Medicine. - 2012. Technical Report AFRL-SA-WPTR-2013-0003. DOI: 10.21236/ada577826

15. Chappelle W. Factor analysis of computer-based Multidimensional Aptitude Battery-Second Edition intelligence testing from rated U.S. Air Force pilots / W. Chappelle, B. Heerema, W. Thompson. - Wright-Patterson AFB (OH): U.S. Air Force School of Aerospace Medicine, - 2012. Technical Report AFRL-SA-WP-TR-2013-0005. DOI: 10.21236/ada583710

16. A Preliminary Investigation into Cognitive Aptitudes Predictive of Overall MQ-1 Predator Pilot Qualification Training Performance / [W. Chappelle, T. Goodman, J. Swearingen, W. Thompson]. - Wright-Patterson AFB (OH): U.S. Air Force School of Aerospace Medicine, - 2015. - Technical Report AFRL-SA-WP-SR-2015-0025. - 14 p.

17. Vigilance and Automation Dependence in Operation of Multiple Unmanned Aerial Systems (UAS): A Simulation Study / [W. Ryan, G. Matthews, J. Lin et al] // Hum Factors. - May 2019. - Vol. 61, № 3. - P. 488-505. DOI: $10.1177 / 0018720818799468$

18. Кукушкин Ю. Методика автоматизированной обработки управляющих движений оператора в прикладных исследованиях надежности эргатических систем / Ю. Кукушкин, С. Айвазян // Кибернетика и программирование. - 2018. - № 5. - С. 15-23. DOI: $10.25136 / 2306-4196.2018 .5 .1817$

19. Гусев Д. Программный комплекс априорного оценивания показателей качества профессиональной деятельности оператора эргатической системы / Д. Гусев, Р. Климов // Программные системы и вычислительные методы. - 2015. № 4. - C. 374-389. DOI: 10.7256/2305-6061.2015.4.17965

20. Visual-motor reactions as an indicator of CNS functional state / [Y. Ignatova, I. Makarova, K Yakovleva, A. Aksenova] // Ulyanovsk Medico-biological Journal. - 2019. - № 3. - P. 3851. DOI: 10.34014/2227-1848-2019-3-38-51

21. Werner L. Probability Theory / L. Werner. - De Gruyter Textbook, 2016. - 395 p. DOI: $10.1515 / 9783110466195$

22. Кулаков А. Особенности простой психофизиологической реакции / А. Кулаков // Физиология человека. - 2018. Том 44, № 4. - C. 60-66. DOI: 10.1134/s0131164618040069 